\title{
Dye Regeneration Kinetics of C343-Sensitized Nickel Oxide Investigated by Scanning Electrochemical Microscopy
}

\author{
Anshebo Getachew Alemu \\ Department of Physics, Faculty of Natural and Computational Science, Samara University, Samara, Ethiopia \\ Email: agetachew2013alemu@yahoo.com
}

How to cite this paper: Alemu, A.G. (2022) Dye Regeneration Kinetics of C343-Sensitized Nickel Oxide Investigated by Scanning Electrochemical Microscopy. Materials Sciences and Applications, 13, 22-38.

https://doi.org/10.4236/msa.2022.131002

Received: October 8, 2021

Accepted: January 18, 2022

Published: January 21, 2022

Copyright ( 2022 by author(s) and Scientific Research Publishing Inc. This work is licensed under the Creative Commons Attribution International License (CC BY 4.0).

http://creativecommons.org/licenses/by/4.0/

\section{(c) (i) Open Access}

\begin{abstract}
Scanning electrochemical microscopy (SECM) feedback mode has been used to investigate kinetics of dye regeneration in DSSC. Organic dye C343 and CW1 are used as sensitizers for nickel oxide (NiO) photoelectrochemical cells. The influence of film thickness on dye regeneration kinetics in the films for $\mathrm{NiO} / \mathrm{C} 343$ for six different films was investigated. SECM was used to analyze effective rate constant, $k_{\text {eff }}$ and reduction rate $k_{\text {red }}$, absorption cross section, $\Phi_{\mathrm{hv}}$ for the dye regeneration process. The data reveal a significant variation of $k_{\text {eff }}$ and $k_{\text {red }}$ with a variation of light intensity, sample thickness and dye difference. This research found remarkable dependence of the dye regeneration kinetic parameters on illumination flux, dye types and film thickness of electrode.
\end{abstract}

\section{Keywords}

Nickel Oxide, Kinetic Parameters, Scanning Electrochemical Microscopy

\section{Introduction}

Recently dye-sensitized solar cells (DSSC) have got much attention due to low production cost, flexibility and transparency relative to other solar cells [1] [2] [3]. Until now a lot of research had been done on sensitization of $n$-type oxides such as titanium dioxide $\left(\mathrm{TiO}_{2}\right)$ and $\mathrm{Zinc}$ oxide $(\mathrm{ZnO})$ [4] [5]. In n-type sensitized oxides an electron is injected into conduction band of semiconductor (n-SC) from the excited state sensitizer. During the past three decades, DSSCs have got much attention as another concept to $\mathrm{p}$ - $\mathrm{n}$ junction photovoltaics, be- 
cause they bargain significantly reduced production costs [6] [7]. Recently PDSSC, has emerged as new generation of photoelectrochemical cells. In p-type DSSC, the photo-excited sensitizer (HOMO) is reductively quenched by hole injection into the valence band of a p-type semiconductor (p-SC) [8] [9].

The operation principles of P-type DSSC depend on process, the sensitizer excited state dye $\mathrm{D}^{*}$ injects a hole into the valence band (VB) of the semiconductor leading to the reduction of the dye $\mathrm{D}$. If the charge recombination reaction between $\mathrm{D}^{-}$and the hole in the valence band $\left(\mathrm{h}^{+} / \mathrm{VB} \mathrm{p}-\mathrm{SC}\right)$ is slow enough; the reduced sensitizer can be intercepted by the redox mediator (M). The injected holes diffuse to the back transparent conducting electrode (TCO) pass into the external circuit and reach the counter electrode where they oxidize the redox mediator back to its original state [10] [11]. A lot of research has been done to explore the parameters that determine the overall performance conversion efficiency and stability. The efforts were made to develop P-type nanostructure films such as $\mathrm{NiO}$ [12], $\mathrm{CuO}$ [13], $\mathrm{CuSCN}$ [14], $\mathrm{CuGaO} 2$ [15], $\mathrm{CuCrO} 2$ [16], and K-doped $\mathrm{ZnO}$ [17] [18], with compared to that given to n-type DSSC. Among the P-type semiconductors, $\mathrm{NiO}$ has got attention because of wide bandgap Eg 3.6 to $4 \mathrm{eV}$ with good stability.

Dye regeneration is a crucial step to avoid charge recombination between photo oxidized dye and the injected electron to minimize dye degradation. The interfacial kinetic process is clearly crucial to the operation of a photoelectrochemical cell. In P-type DSSC, regeneration depends on hole injection and recombination of electrons with holes in valance band of p-type oxides. The film thickness can significantly influence the regeneration kinetics and photovoltaic performance of dye sensitized solar cells [19] [20]. The time-resolved spectroscopy (TRTS) was developed to analyze kinetics of electron transfer at dye-sensitized solar cells to describe the rate constant of electron transfer of interface [21] [22] [23] [24]. Moreover, scanning electrochemical microscopy has been demonstrated to be an effective technique for determining ET kinetics at various interfaces, including polymer/liquid, [25] and liquid/liquid ones, [26] and redox enzymes [27]. Recently Prof. G. Wittstock group at University of Oldenburg Germany reported scanning electrochemical microscopy is a new tool to study electron transfer at dye sensitized semiconductor/electrolyte interface. They reported $\mathrm{ZnO} /$ Eosin $\mathrm{Y}$, ruthenium (II)-sensitized $\mathrm{TiO}_{2}$, and $\mathrm{ZnO} / \mathrm{D} 149$ interface regeneration kinetics [28] [29].

In this study, we $\mathrm{NiO} / \mathrm{C} 343$ films of different film thicknesses were prepared by varying the $\mathrm{NiO}$ dip coating deposition method overnight in the $\mathrm{C} 343$. In addition, the kinetics of C343 and CW1 regeneration by iodide ions in the electrolyte was studied using an SECM feedback mode approach for different thickness and different illumination intensity. The reduced electrolyte $\left(\mathrm{I}^{-}\right)$in acetonitrile solvent with supporting electrolyte LiTFS is used as a mediator [29]. This paper's first section presented a comparative study of SECM dye regeneration of C343 and CW1 dyes as shown in Figure 1. The second section discussed SECM kinetic parameters of $\mathrm{C} 343$ dye sensitized $\mathrm{NiO}$ film with different thicknesses. 


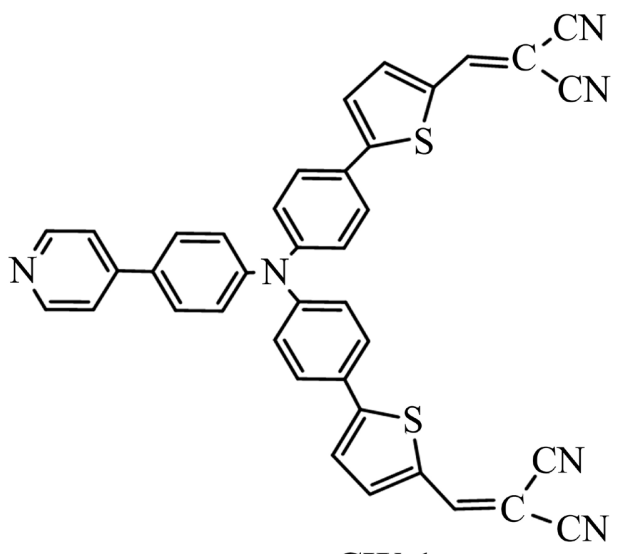

(a)<smiles>O=C(O)c1cc2cc3c4c(c2oc1=O)CCCN4CCC3</smiles>

C343

(b)

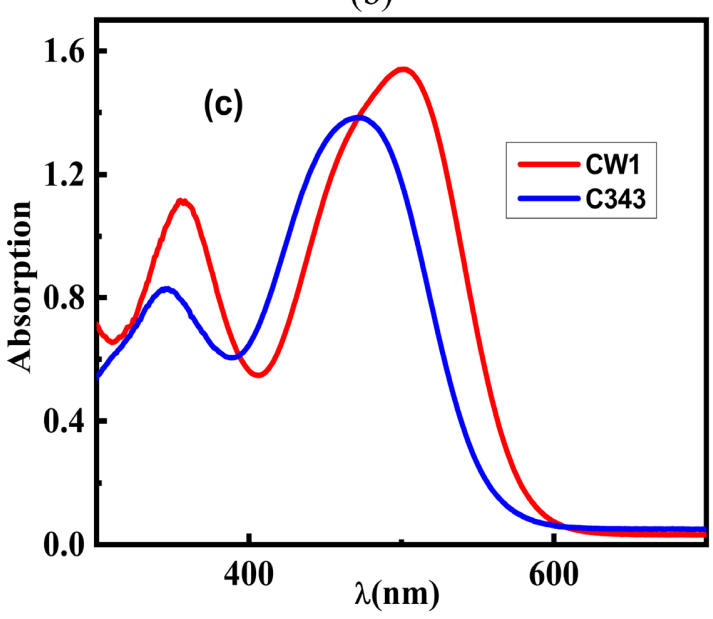

Figure 1. Chemical structure of (a) CW1; (b) C343 dyes; (c) Absorbance of CW1 and C343 dyes.

\section{Experimental Section}

\subsection{Preparation of the NiO/Dye Film}

Nickel Oxide (NiO) nanoparticles (particle size 20 nm, 99.9\%, Informant Advanced Materials) were ball-milled in ethanol with few droplets of acetate. The mixture of above colloidal solution, ethyl cellulose (Aldrich) and terpinol anhydrous ( $\geq 99.5 \%$, Fluka) were sonicated and stirred alternatively to obtain a fine dispersion. A paste was made by evaporating the ethanol from the mixture on a 
rotary evaporator. FTO glass (Nippon sheet glass, resistance $13 \Omega /$ square) were coated with nickel acetate ( $+98 \%$, Alfa Aesar) ethanol ( $\geq 99.7 \%$, Merck) solution $(0.05 \mathrm{M})$ by dip coating and subsequently dried before screen print [30] [31].

\subsection{SECM Apparatus and Procedure}

SECM experiments were performed on cell contained a Pt wire counter electrode and a Pt wire quasi-reference electrode. Positioning was performed with an x-y-z stepper motor system. A Pt wire radius $12.5 \mu \mathrm{m}$ was sealed into a $5 \mathrm{~cm}$ Pyrex glass capillary under vacuum. The UME was polished and shaped conically by a wheel with 180-grid Carbimet paper disks and micro polishing cloths with $0.3 \mu \mathrm{m}$ for 3 minuties. The UME was sharpened to RG 10, where RG is the ratio of the diameters of the glass sheath and the Pt wire. Before each experiment, the UME was polished with $0.3 \mu \mathrm{m}$ powder, rinsed with water and ethanol. The sensitized $\mathrm{NiO}$ electrode was placed at the bottom of a small volume electrochemical cell and short circuited by a Pt wire to the electrolyte. The emission spectra of the LEDs compared with the absorption spectrum of NiO/C343 and $\mathrm{NiO} / \mathrm{CW} 1$ film. The LEDs were placed close to the cell and focused on the dye-sensitized film by an objective lens (so that the photo-illuminated spot had a diameter of about $\left(0.0785 \mathrm{~cm}^{2}\right)$ [32] [33] [34] [35].

\section{Results and Discussion}

\subsection{SECM Measurement of the Dye Regeneration Rate}

According to various applications SECM has been a prevailing technique for probing interface kinetics [36] [37]. SECM feedback mod based on an ultra microelectrode (UME) to substrate and subsequent its current response as a function of the distance from the surface provide dye regeneration kinetics in sensitized solar cells [19] [38] [39] [40] [41]. In feedback mode scanning probe based on the motion of ultra microelectrode (tip) close to the surface of conductive or non-conducting (insulting) substrate. For the UME, tip reaction for charge transfer reaction and the study state current of given by Equation (1a) and Equation (1b) respectively

$$
\begin{gathered}
\mathrm{O}+n \mathrm{e}^{-} \rightarrow \mathrm{R} \\
I_{T \infty}=4 n F\left(\frac{k_{\mathrm{eff}}}{\kappa}\right) C r_{T}^{2}
\end{gathered}
$$

where, $F$ : Faraday's constant, $n$ is number of electrons transferred in reaction Equation (1b), $k_{\text {eff }}$ reaction rate constant, $C$ is concentration of electrolyte, $r_{T}$ is $\mathrm{UME}$ radius and $\kappa$, normalized rate constant.

The photon induces electrochemical reaction on the $\mathrm{NiO} /$ dye surface a change of the tip current as the UME approaches the interface. In order to scrutinize the kinetics of dye regeneration we measured SECM current-distance curves of dye sensitized $\mathrm{NiO}$ film with blue illumination in different wavelengths. The effect of illumination intensity on the kinetics of dye regeneration was studied by measuring approach curves at different $J_{\mathrm{hv}}$, its value increases clearly as the $J_{\mathrm{hv}}$ is in- 
creased. The kinetics of regeneration by the electrolyte was studied using SECM feedback mode approach on the NiO films with two dyes of C343 and CW1 different intensity as documented in Table 1 and Table 2.

Figure 2(a) shows the normalized curve at UME to $\mathrm{CW} 1 / \mathrm{NiO}$ under blue LED illumination photon flux increased from $2.2 \times 10^{-9} \mathrm{~mol} \cdot \mathrm{cm}^{-2} \cdot \mathrm{s}^{-1}$ to $22.4 \times$ $10^{-9} \mathrm{~mol} \cdot \mathrm{cm}^{-2} \cdot \mathrm{s}^{-1}$. The rate constant $k_{\text {eff }}$ increased from $1.45 \times 10^{-3}$ to $8.18 \times 10^{-3}$ $\mathrm{cm} \cdot \mathrm{s}^{-1}$ in blue LED for CW1/NiO. Figure 2(b) shows the normalized curve at $\mathrm{NiO} / \mathrm{C} 343$ under illumination with blue LED at different intensities. The rate constant $k_{\text {eff }}$ of $\mathrm{NiO} / \mathrm{C} 343$, increased from $0.92 \times 10^{-3}$ to $4.93 \times 10^{-3} \mathrm{~cm} \cdot \mathrm{s}^{-1}$ in blue LED as documented in Table 1.

Figure 3(a) shows the normalized approach curve on $\mathrm{C} 343 / \mathrm{NiO}$ under red illumination flux density increased from $2.12 \times 10^{-9} \mathrm{~mol} \cdot \mathrm{cm}^{-2} \cdot \mathrm{s}^{-1}$ to $14.7 \times 10^{-9}$ $\mathrm{mol} \cdot \mathrm{cm}^{-2} \cdot \mathrm{s}^{-1}$ its rate constant $k_{\text {eff }}$ increased from $2.43 \times 10^{-3}$ to $7.39 \times 10^{-3} \mathrm{~cm} \cdot \mathrm{s}^{-1}$. Figure $3(\mathrm{~b})$ shows the approach curve on $\mathrm{NiO} / \mathrm{CW} 1$ under illumination with red illumination at different intensities rate constant increased from $1.82 \times 10^{-3}$ to $5.64 \times 10^{-3} \mathrm{~cm} \cdot \mathrm{s}^{-1}$ in red LED as documented in Table 2 .

Generally, according to several studies illuminated dye excited $\left(\mathrm{D}^{*}\right)$ injects a hole into the valence band (VB) of the P-type semiconductor succeed to the reduction of the dye $\left(\mathrm{D}^{-}\right)$. There are a number of reactions mechanism of dye regeneration in P-type DSSC most likely by 2a-e [42] [43]. The regeneration of the dye at the dye-sensitized electrode-electrolyte interface. Therefore, at the illuminated D-sensitized $\mathrm{NiO}$ electrode-electrolyte-UME probe [44] [45]:

Table 1. Normalized rate constants $k_{\text {eff }}$ of CW1/NiO and C343/NiO in blue illumination $D=1.86 \times 10^{-5} \mathrm{~cm}^{2} \cdot \mathrm{s}^{-1}, r_{T}=12.5 \mathrm{~lm}, k_{\text {eff }}=\kappa D / r_{T}$.

\begin{tabular}{cccc}
\hline$J_{\mathrm{hv}} / 10^{-9} \mathrm{~mol} \cdot \mathrm{cm}^{-2} \cdot \mathrm{s}^{-1}$ & Curve $\#$ & $k$ & $k_{\mathrm{eff}} / 10^{-3} \mathrm{~cm} \cdot \mathrm{s}^{-1}$ \\
\hline (a) CW 1 & 1 & 0.067 & 1.45 \\
2.2 & 2 & 0.132 & 3.48 \\
6.1 & 3 & 0.156 & 3.79 \\
6.8 & 4 & 0.178 & 5.62 \\
11.8 & 5 & 0.189 & 6.25 \\
13.9 & 6 & 0.214 & 7.67 \\
19.8 & 7 & 0.219 & 8.18 \\
22.4 & & & \\
(b) C343 & 1 & 0.065 & 0.92 \\
2.2 & 2 & 0.129 & 2.18 \\
6.1 & 3 & 0.137 & 2.37 \\
6.8 & 4 & 0.174 & 3.46 \\
11.8 & 5 & 0.185 & 3.82 \\
13.9 & 6 & 0.205 & 4.64 \\
19.8 & 7 & 0.213 & 4.93 \\
22.4 & & &
\end{tabular}


Table 2. Normalized rate constants $k_{\text {eff }}$ of $\mathrm{C} 343 / \mathrm{NiO}$ and $\mathrm{CW} 1 / \mathrm{NiO}$ in red illumination $D$ $=1.86 \times 10^{-5} \mathrm{~cm}^{2} \cdot \mathrm{s}^{-1}, r_{T}=12.5 \mu \mathrm{m}, k_{\mathrm{eff}}=\kappa D / r_{T}$

\begin{tabular}{cccc}
\hline$J_{\mathrm{hv}} / 10^{-9}\left(\mathrm{~mol} \cdot \mathrm{cm}^{-2} \cdot \mathrm{s}^{-1}\right)$ & Curve & $k$ & $k_{\mathrm{eff}} / 10^{-3} \mathrm{~cm} \cdot \mathrm{s}^{-1}$ \\
\hline (a) C343 & 7 & 0.0484 & 7.39 \\
14.7 & 6 & 0.0457 & 7.09 \\
13.1 & 5 & 0.0444 & 6.89 \\
12.1 & 4 & 0.0401 & 6.21 \\
9.4 & 3 & 0.0342 & 5.31 \\
6.8 & 2 & 0.0271 & 4.01 \\
4.2 & 1 & 0.0163 & 2.43 \\
2.12 & & & \\
(b) CW1 & 7 & 0.0379 & 5.64 \\
14.7 & 6 & 0.0363 & 5.41 \\
13.1 & 5 & 0.0352 & 5.24 \\
12.1 & 4 & 0.0317 & 4.72 \\
9.4 & 3 & 0.0271 & 4.02 \\
6.8 & 2 & 0.0202 & 3.01 \\
4.2 & 1 & 0.0122 & 1.82 \\
2.12 & & &
\end{tabular}
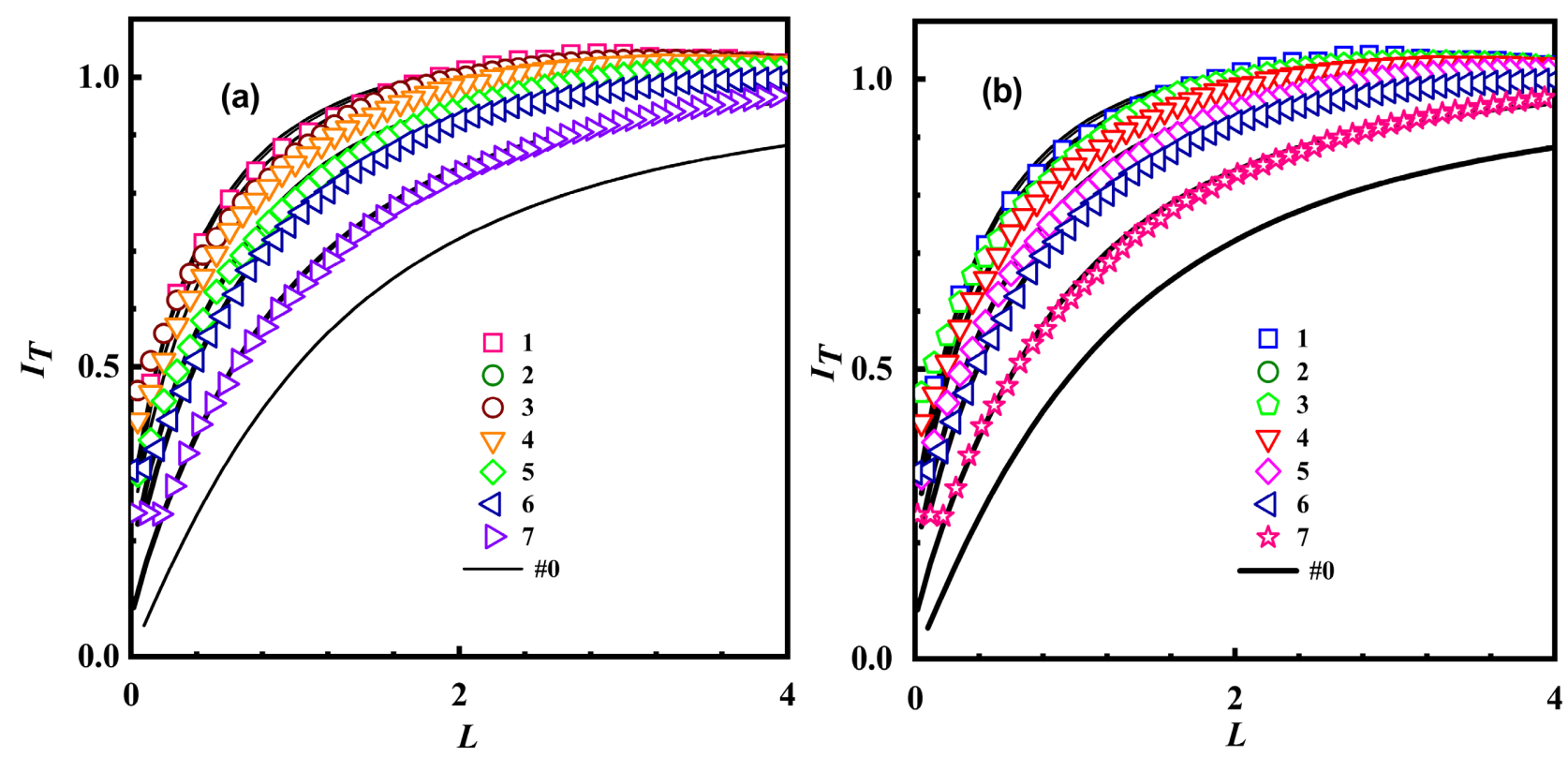

Figure 2. Normalized SECM feedback approach curves for the approach of a Pt disk UME towards (a) NiO/C343, (b) NiO/CW1.

$$
\begin{gathered}
\mathrm{NiO} / \mathrm{D}+\mathrm{hv} \rightarrow \mathrm{D}^{*} / \mathrm{NiO}: \text { excitation } \\
\mathrm{NiO} / \mathrm{D}^{*} \stackrel{\text { hv }}{\longrightarrow} \mathrm{D}^{-} \rightarrow \mathrm{h}^{+} / \mathrm{NiO}: \text { chargr separation } \\
\mathrm{NiO}\left(\mathrm{h}^{+}\right)+\mathrm{D}^{-} \rightarrow \mathrm{NiO} / \mathrm{D}: \text { germinate recombination }
\end{gathered}
$$



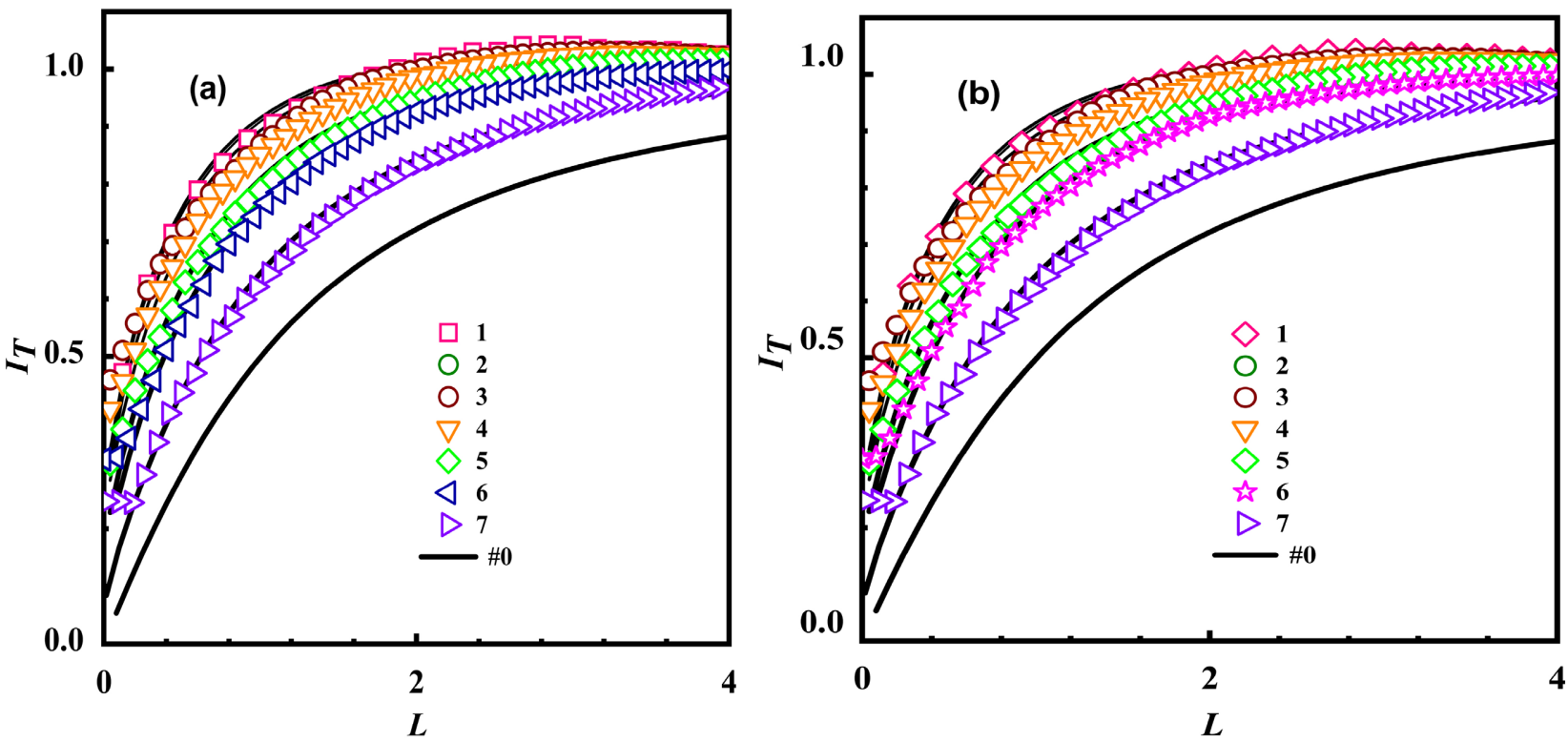

Figure 3. Normalized feedback approach curves for the approach of a Pt disk UME towards (a) NiO/C343, (b) NiO/CW1 in red illumination.

$$
\begin{gathered}
\mathrm{NiO}\left(\mathrm{h}^{+}\right) / \mathrm{D}^{-}+\mathrm{I}_{3}^{-} \rightarrow \mathrm{D} / \mathrm{NiO}(+)+\mathrm{I}_{2}^{-}+\mathrm{I}^{-} \text {: regeneration } \\
3 \mathrm{I}^{-}-\mathrm{e}^{-} \rightarrow \mathrm{I}_{3}^{-} \text {: regeneration on the UME }
\end{gathered}
$$

when illuminated dye is excited there is charge separation and a hole injection into the $\mathrm{NiO}$ valence band, and the dye is reduced. Then dye will react with the oxidized species of the electrolyte $\left(\mathrm{I}_{3}^{-}\right)$and regenerate to its ground state. Under illumination excited dye injects holes to valance band $\mathrm{NiO}$ oxide (charge separation) represented by Equation (2b) heterogeneous electron transfer (regeneration) $\mathrm{I}_{3}^{-} / \mathrm{D}^{-}$Equation (2d). In order to rationalize influence of light on dye regeneration we performed measurement at two different dyes in blue LED in different intensity as shown in Figure 2 \& Figure 3.

Figure 4 shows the plot $k_{\text {eff }}$ vs $J_{\mathrm{h} v}$ for CW1 and C343 sensitized (a) in blue illumination and (b) in red illumination. An experiment values of $k_{\text {red }}=6.95 \times 10^{5}$ $\mathrm{mol}^{-1} \cdot \mathrm{cm}^{3} \cdot \mathrm{s}^{-1}$ and $\Phi_{\mathrm{hv}}(\lambda)=3.16 \times 10^{6} \mathrm{~cm}^{2} \cdot \mathrm{mol}^{-1}$ for C343 blue, LED, respectively. An experiment values of $k_{\text {red }}=7.95 \times 10^{5} \mathrm{~mol}^{-1} \cdot \mathrm{cm}^{3} \cdot \mathrm{s}^{-1}$ and $\Phi_{\mathrm{hv}}(\lambda)=3.32 \times 10^{6}$ $\mathrm{cm}^{2} \cdot \mathrm{mol}^{-1}$ for CW1 in the blue, LED, respectively Table 3 . When the sensitized $\mathrm{NiO}$ film back-illuminated, the ground state dye is denoted by $\mathrm{D}$, photo-reduced dyes $\mathrm{D}^{-}$and photo excited dye molecules $\mathrm{D}^{*}$. The mathematical expression for excited dye $\mathrm{D}^{*}$ can be derivative from the mass conservation and the steady-state approximations for surface concentrations of the photo excited dye represented by Equation (3a) the reduced dye Equation (3b)

$$
\begin{gathered}
\frac{\partial \Gamma_{\mathrm{D}^{*}}}{\partial t}=\phi_{\mathrm{hv}} J_{\mathrm{hv}} \Gamma_{\mathrm{D}}-k_{\mathrm{inj}} \Gamma_{\mathrm{D}^{*}} \\
\frac{\partial \Gamma_{\mathrm{D}^{-}}}{\partial t}=k_{\mathrm{red}} \Gamma_{\mathrm{D}^{-}}\left[\mathrm{I}_{3}^{-}\right]_{S}^{1 / 2}+k_{\mathrm{inj}} \Gamma_{\mathrm{D}^{*}}
\end{gathered}
$$



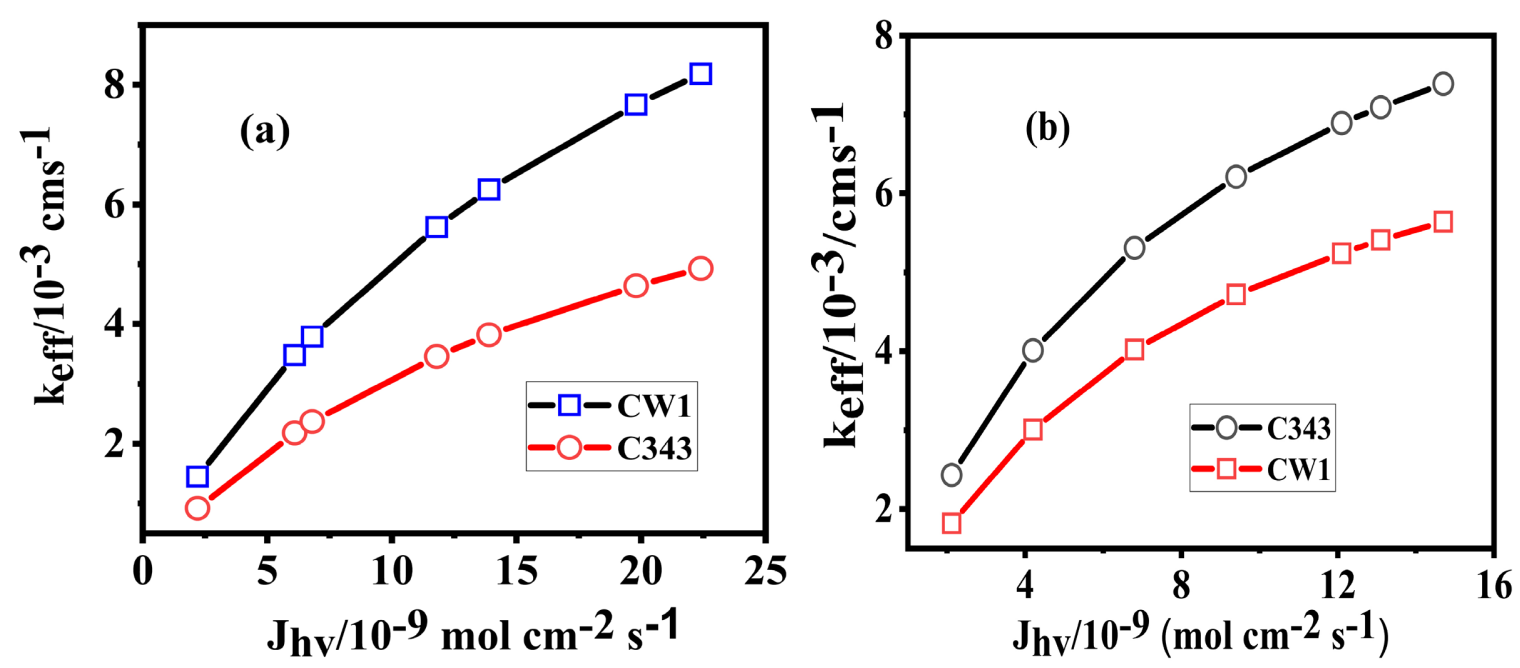

Figure 4. $k_{\text {eff }}$ vs $J_{\text {hv }}$ for (a) CW1 and (b) C343 sensitized NiO films in blue and red LED.

Table 3. Regeneration parameters for $\mathrm{C} 343 / \mathrm{NiO}$ and $\mathrm{CW} 1 / \mathrm{NiO}$ in blue illumination.

\begin{tabular}{cccc}
\hline Dye & $k_{\mathrm{red}} / \mathrm{mol}^{-1} \cdot \mathrm{cm}^{3} \cdot \mathrm{s}^{-1}$ & $\Phi_{\mathrm{hv}} / \mathrm{cm}^{2} \cdot \mathrm{mol}^{-1}$ & Illumination \\
\hline C343 & $6.95 \times 10^{5}$ & $3.16 \times 10^{6}$ & Blue \\
CW1 & $7.95 \times 10^{5}$ & $3.32 \times 10^{6}$ & Blue \\
\hline
\end{tabular}

Thus, the rate constants $k_{\text {red }}$ for the regeneration of the reduced dye after injection the hole into the valance band of P-type semiconductor by the reduced state of redox at incident light of given by Equation (4). A kinetic analysis rate constant $k_{\text {eff }}$, for regeneration processes expressed in terms of reduction rate constant $k_{\text {red }}$, absorption cross-section of dye $\phi_{\text {hv }}$, thickness of sample $L$, dye concentration on $\mathrm{NiO}$ film $D^{o}$ and electrolyte concentration $\left[\mathrm{I}^{-}\right]$as

$$
\frac{1}{k_{\mathrm{red}}}=\frac{2 L}{D^{o}}\left(\frac{\left[\mathrm{I}^{-}\right]}{\phi_{\mathrm{hv}} J_{\mathrm{hv}}}+\frac{1}{k_{\mathrm{eff}}}\right)
$$

where, $k_{\text {eff }}$ represents the regeneration rate, and $\Phi_{\mathrm{hv}}$ absorption rate.

Due to dependence of regeneration on illumination wave length, result in different values of $k_{\text {eff }}$ of the different wavelengths. Under illumination of the thin film with blue LED incident photon fluxes the rate constants extracted by fitting $k_{\text {red }}$ of $7.95 \times 10^{5} \mathrm{~mol}^{-1} \cdot \mathrm{cm}^{3} \cdot \mathrm{s}^{-1}$ for CW1 $\Phi_{\mathrm{hv}}$ of $3.3 \times 10^{6} \mathrm{~cm}^{2} \cdot \mathrm{mol}^{-1}$ and $6.73 \times 10^{5}$ $\mathrm{mol}^{-1} \cdot \mathrm{cm}^{3} \cdot \mathrm{s}^{-1}$ for $\mathrm{C} 343, \Phi_{\mathrm{hv}}$ of $2.3 \times 10^{6} \mathrm{~cm}^{2} \cdot \mathrm{mol}^{-1}$.

\subsection{SECM Approach Curves of Different Thickness}

A number of studies on film thickness state to macroscopic characteristics of dye sensitized solar cells parameters depend on the rate of charge transfer reactions. SECM feedback analysis permitted to investigate dye regeneration kinetics at a microscopic sample [46] [47] [48] [49]. The film thickness has implicitly affected on the performance of dye sensitized solar cells which increase the accumulation probability, which promotes more light absorption [19] [20]. In order to inves- 
tigate the effect of dye thickness absorption spectra of C343 adsorbed on the porous $\mathrm{NiO}$ films of varied thickness as shown in (Table 4). In this work, we used six samples with $\mathrm{t}$ thickness $(2.8 \mu \mathrm{m}, 34 \mu \mathrm{m}, 3.8 \mu \mathrm{m}, 4.4 \mu \mathrm{m} 5.4 \mu \mathrm{m}$, and 5.8 $\mu \mathrm{m}$ respectively). Figure 5(a) shows absorption spectra of C343 adsorbed on the porous $\mathrm{NiO}$ films in different thicknesses. The spectra clearly show broad absorption bands peaking at approximately $490 \mathrm{~nm}$, superimposed to a background signal due to scattering of light by the nickel oxide film. This proves the successful saturation of the films with the dye of the pores for all films. The film thickness is in line with the trend of peak heights in the solid-state absorption on the surface $\mathrm{NiO}$ spectra, pick highest for $5.8 \mu \mathrm{m}$ and minimum spectra pick for $2.8 \mu \mathrm{m}$.

Figure 5(b) shows the normalized SECM approach curves recorded with $\mathrm{Pt}$ UME $\left(r_{T}=12.5 \mathrm{~mm}\right)$ approaching to $\mathrm{C} 343 / \mathrm{NiO}$ films of thickness of $38 \mu \mathrm{m}$ illuminated at different $J_{\mathrm{hv}}$. The $k_{\text {eff }}$ value obtained at the illuminated C343/NiO film, increases as the $J_{\text {hv }}$ increased. Increasing $J_{\text {hv }}$ increased hence $k_{\text {eff }}$ as shown in Table 3. As $J_{\text {hv }}$ increased from $2.21 \times 10^{-9} \mathrm{~mol} \cdot \mathrm{cm}^{-2} \cdot \mathrm{s}^{-1}$ to $22.4 \times 10^{-9} \mathrm{~mol} \cdot \mathrm{cm}^{-2} \cdot \mathrm{s}^{-1}$, the cross ponding increased from $1.87 \times 10^{-3} \mathrm{~cm} \cdot \mathrm{s}^{-1}$ to $7.73 \times 10^{-3} \mathrm{~cm} \cdot \mathrm{s}^{-1}$. The result revealed that the normalized approach curves depend on the thickness of the film. SECM approach curves of the other films recorded on supporting information. Figure 5(d) shows the $L\left(10^{-6} \mathrm{~m}\right)$ vs $k_{\text {red }}, \Phi_{\mathrm{hv}}$ for six samples as shown Table 5. As film thickness increases the absorption crossection increases because when thickness of sample increases the dye deposition increase, it provides probability of much light absorption as shown Figure 5(d). In contrary as film

Table 4. Normalized rate constants $k_{\text {eff }}$ of $\mathrm{C} 343 / \mathrm{NiO}$ for different film thickness in blue illumination.

\begin{tabular}{rcccccc}
\hline$J_{\text {hv }} / 10^{-9}$ & $\mathrm{~S}_{28}$ & $\mathrm{~S}_{34}$ & $\mathrm{~S}_{38}$ & $\mathrm{~S}_{44}$ & $\mathrm{~S}_{54}$ & $\mathrm{~S}_{58}$ \\
\hline 22.4 & 7.65 & 8.57 & 7.73 & 7.38 & 9.75 & 10.17 \\
19.8 & 7.29 & 8.18 & 7.39 & 7.11 & 9.38 & 9.87 \\
13.9 & 6.21 & 7.19 & 6.39 & 6.22 & 8.24 & 8.92 \\
11.8 & 5.71 & 6.44 & 5.91 & 5.81 & 7.68 & 8.44 \\
6.12 & 3.81 & 4.33 & 4.05 & 4.08 & 5.45 & 6.33 \\
2.21 & 1.71 & 1.96 & 1.87 & 1.94 & 2.61 & 3.28 \\
\hline
\end{tabular}

Table 5. Regeneration parameters $\Phi_{\mathrm{hv}}$ and $k_{\text {red }}$, of C343 by I-for different film thickness.

\begin{tabular}{ccc}
\hline$L / 10^{-6} \mathrm{~m}$ & $\Phi_{\mathrm{hv}} / 10^{6}\left(\mathrm{~cm}^{2} \cdot \mathrm{mol}^{-1}\right)$ & $k_{\mathrm{red}} / 10^{5}\left(\mathrm{~mol}^{-1} \cdot \mathrm{cm}^{3} \cdot \mathrm{s}^{-1}\right)$ \\
\hline 28 & 3.713 & 5.647 \\
34 & 3.893 & 5.457 \\
38 & 4.275 & 4.979 \\
44 & 4.979 & 4.547 \\
54 & 5.269 & 3.947 \\
58 & 5.579 & 3.877 \\
\hline
\end{tabular}



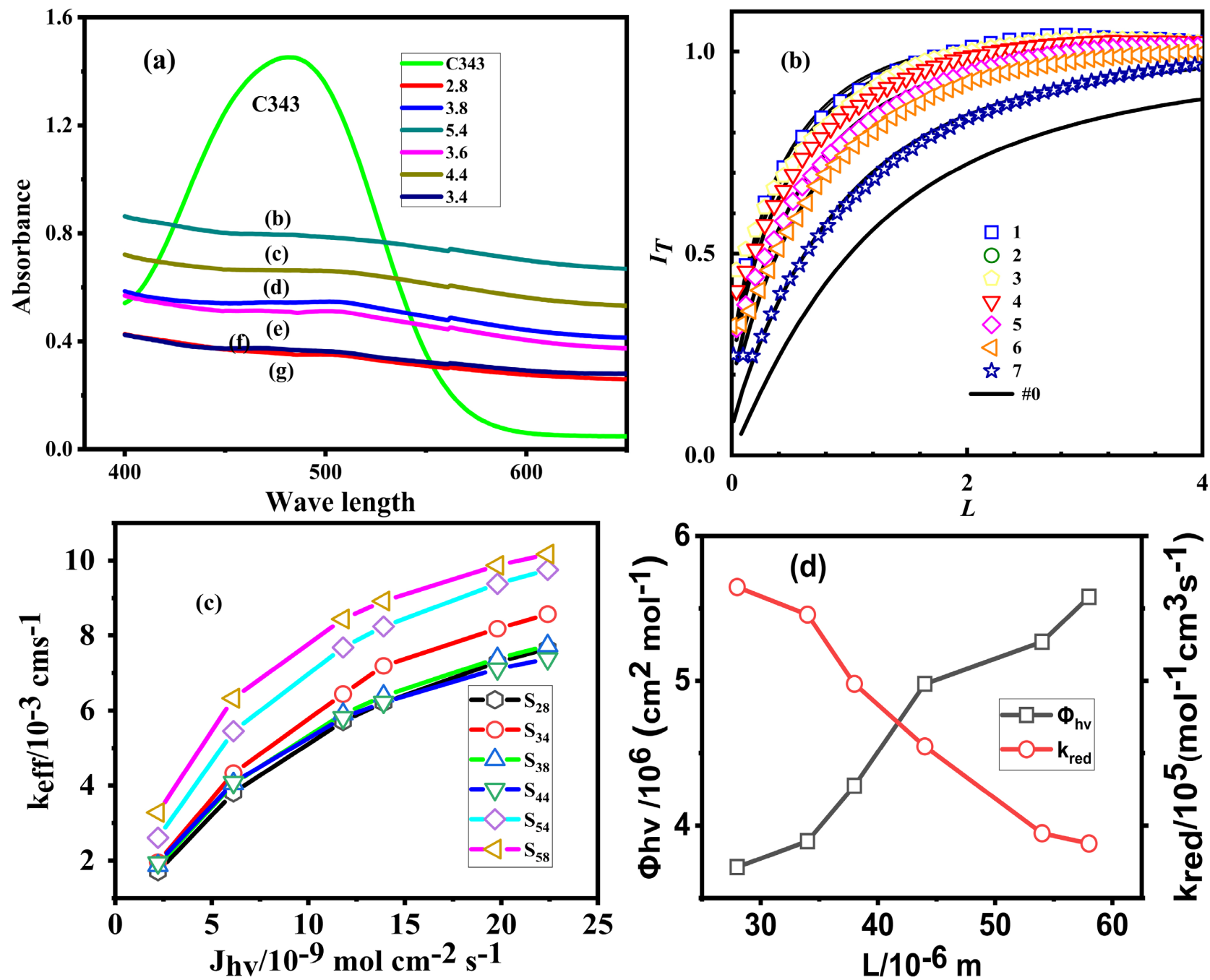

Figure 5. (a) Optical absorption spectra of NiO/C343 films of different thickness; (b) SECM approach curves obtained with Pt UME $\left(r_{T}=12.5 \mathrm{~mm}\right)$ on C343-NiO films; (c) $k_{\text {eff }}$ vs. $J_{\text {hv }}$ for six different C343/NiO photoelectrodes with systematically varied thickness; (d) $k_{\text {red }}$ vs Thickness of film.

thickness increases the regeneration rate constant decrease due to, the dye concentration increases on surface of film, the reaction rate on the sample surface is faster than the UME reaction.

\section{Conclusion}

The dye regeneration kinetics were studied on different film thicknesses of C343sensitized $\mathrm{NiO}$ photoelectrodes. The clear difference of regeneration parameters was analyzed for $\mathrm{CW} 1 / \mathrm{NiO}$ and $\mathrm{C} 343 / \mathrm{NiO}$, and there was significant variation for both dyes regeneration parameters in different wave length of illumination. It was found that SECM feedback approach curve analysis, considerably different rate constants $k_{\text {red }}$, and absorption cross section area $\Phi_{\mathrm{hv}}$ for the C343/NiO were measured for the photoelectrodes of systematically varied $\mathrm{NiO}$ thickness. Investigation of SECM kinetic model shows significant different effective C343 regeneration rate constants $k_{\text {red }}$ and absorption cross section $\Phi_{\text {hv }}$ for $\mathrm{C} 343-\mathrm{NiO}$ 
electrodes of systematically varied film thickness.

\section{Acknowledgements}

Dr. Anshebo Getachew Alemu thanks Chinese Scholarship Counsel (CSC) for PhD fellowship. The authors thank Prof. Dr. Mingkui Wang, and Prof. Dr. Yen Shen for their helpful comments.

\section{Conflicts of Interest}

The author declares no conflicts of interest regarding the publication of this paper.

\section{References}

[1] O’Regan, B. and Grätzel, M. (1991) A Low-Cost, High-Efficiency Solar Cell Based on Dye-Sensitized Colloidal $\mathrm{TiO}_{2}$ Films. Nature, 353, 737-740. https://doi.org/10.1038/353737a0

[2] Grätzel, M. (2005) Solar Energy Conversion by Dye-Sensitized Photovoltaic Cells. Inorganic Chemistry, 44, 6841-6851. https://doi.org/10.1021/ic0508371

[3] Grätzel, M. (2001) Photoelectrochemical Cells. Nature, 414, 338-344. https://doi.org/10.1038/35104607

[4] Zhang, Q. and Cao, G. (2011) Nanostructured Photoelectrodes for Dye-Sensitized Solar cells. Nanotoday, 6, 91-109. https://doi.org/10.1016/j.nantod.2010.12.007

[5] Zhang, Q., Dandeneau, C.S., Zhou, X. and Cao, G. (2009) ZnO Nanostructures for Dye-Sensitized Solar Cells. Advanced Materials, 21, 4087-4108. https://doi.org/10.1002/adma.200803827

[6] Yella, A., Lee, H.-W., Tsao, H.N., Yi, C., Chandiran, A.K., Nazeeruddin, M.K., Diau, E.W.-G., Yeh, C.-Y., Zakeeruddin S.M. and Grätzel, M. (2011) Porphyrin-Sensitized Solar Cells with Cobalt (II/III)-Based Redox Electrolyte Exceed 12 Percent Efficiency. Science, 334, 629-634. https://pubmed.ncbi.nlm.nih.gov/22053043/ https://doi.org/10.1126/science.1209688

[7] Haque, S.A., Palomares, E., Cho, B.M., Green, A.N.M., Hirata, N., Klug, D.R. and Durant, J.R. (2005) Charge Separation versus Recombination in Dye-Sensitized Nanocrystalline Solar Cells: The Minimization of Kinetic Redundancy. Journal of the American Chemical Society, 127, 3456-3462. https://doi.org/10.1021/ja0460357

[8] Gibson, E.A., Plux, L.L., Fortage, J., Pellegrin, Y., Blart, E., Odoble, F., Hagfeldt, A. and Boschloo, G. (2012) Role of the Triiodide/Iodide Redox Couple in Dye Regeneration in p-Type Dye-Sensitized Solar Cells. Lagmuir, 28, 6485-6493. https://doi.org/10.1021/la300215q

[9] Wang, Z.Y., Wang, L., Zhang, Y., Guo, J.N., Li, H. and Yan, Y. (2017) Dye-Sensitized Solar Cells Based on Cobalt Containing Room Temperature Ionic, Liquid Redox Shuttles. RSC Advances, 7, 13689-13695. https://doi.org/10.1039/C6RA26402F

[10] Odobel, F., Pleux, L., Pellegrin, Y. and Blart, L (2010) New Photovoltaic Devices Based on the Sensitization of p-Type Semiconductors: Challenges and Opportunities. Accouncts of Chemical Research, 43, 1063-1071. https://doi.org/10.1021/ar900275b

[11] Nattestad, A., Ferguson, M., Kerr, R., Cheng, Y.B. and Bach, U. (2008) Dye-Sensitized Nickel(II) Oxide Photocathodes for Tandem Solar Cell Applications. Nanotechnology, 19, Article No. 295304. https://doi.org/10.1088/0957-4484/19/29/295304

[12] Fernando, C.A.N., Kitagawa, A., Suzuki, M., Takahashi, K. and Komura, T. (1994) Photoelectrochemical Properties of Rhodamine-C18 Sensitized p-CuSCN Photoe- 
lectrochemical Cell (PEC). Solar Energy Materials and Solar Cells, 33, 301-315. https://doi.org/10.1016/0927-0248(94)90233-X

[13] Yu, M.Z, Natu, G., Ji, Z.Q. and Wu, Y.Y. (2012) p-Type Dye-Sensitized Solar Cells Based on Delafossite $\mathrm{CuGaO} 2 \mathrm{Nanoplates}$ with Saturation Photovoltages Exceeding $460 \mathrm{mV}$. The Journal of Physical Chemistry Letters, 3, 1074-1078.

https://doi.org/10.1021/jz3003603

[14] Euser, T.G., Harding, P.J. and Vos, W.L. (2009) Broadband Sensitive Pump-Probe Setup for Ultrafast Optical Switching of Photonic Nanostructures and Semiconductors. Review of Scientific Instruments, 80, 073104. https://pubmed.ncbi.nlm.nih.gov/ https://doi.org/10.1063/1.3156049

[15] Nechay, B.A., Siegner, U., Achermann, M., Bielefeldt, H. and Keller, U. (1999) Femtosecond Pump-Probe Near-Field Optical Microscopy. Review of Scientific Instruments, 70, Article No. 2758. https://doi.org/10.1063/1.1149841

[16] Azima, A., Düsterer, S., Radcliffe, P., Redlin, H., Stojanovic, N., Li, W., Schlarb, H., Feldhaus, J., Cubaynes, D., Meyer, M., Hayden, P., Hough, P., et al. (2009) TimeResolved Pump-Probe Experiments beyond the Jitter Limitations at FLASH. Applied Physics Letters, 94, Article ID: 144102. https://doi.org/10.1063/1.3111789

[17] Xiong, D.H., Xu, Z., Zeng, X.W., Zhang, W.J., Chen, W., Xu, X.B., Wang, M.K. and Cheng, Y.B. (2012) Hydrothermal Synthesis of Ultrasmall $\mathrm{CuCrO}_{2} \mathrm{Nanocrystal}_{\mathrm{Al}}$ ternatives to $\mathrm{NiO}$ Nanoparticles in Efficient p-Type Dye-Sensitized Solar Cells. Journal of Materials Chemistry, 22, 24760-24768. https://doi.org/10.1039/c2jm35101c

[18] Cui, J., Li, P.F., Chen, Z.F., et al. (2016) Phosphor Coated NiO-Based Planar Inverted Organometallic Halide Perovskite Solar Cells with Enhanced Efficiency and Stability. Applied Physics Letters, 109, Article ID: 171103. https://doi.org/10.1063/1.4965838

[19] Keis, K., Magnusson, E., Lindstrom, H., Lindquist, S.-E. and Hagfeldt, A. (2002) A 5\% Efficient Photo Electrochemical Solar Cell Based on Nanostructured ZnO Electrodes. Solar Energy Materials and Solar Cells, 73, 51-58. https://doi.org/10.1016/S0927-0248(01)00110-6

[20] Ito, S., Zakeeruddin, S.M., Humphry-Baker, R., Liska, P., Charvet, R., Comte, P., Nazeerudd in, M.K., Pechy, P., Taketa, M., Miura, H., Uchida, S. and Grätzel, M. (2006) High-Efficiency Organic-Dye-Sensitized Solar Cells Controlled by Nanocrystalline- $\mathrm{TiO}_{2}$ Electrode Thickness. Advanced Materials, 18, 1202-1205. https://doi.org/10.1002/adma.200502540

[21] Martini, L.A., Moore, G.F., Milot, R.L., et al. (2013) Modular Assembly of HighPotential Zinc Porphyrin Photosensitizers Attached to $\mathrm{TiO}_{2}$ with a Series of Anchoring Groups. The Journal of Physical Chemistry C, 117, 14526-14533. https://doi.org/10.1021/jp4053456

[22] Turner, G.M., Beard, M.C. and Schmuttenmaer, C.A. (2002) Carrier Localization and Cooling in Dye-Sensitized Nanocrystalline Titanium Dioxide. The Journal of Physical Chemistry B, 106, 11716-11719. https://doi.org/10.1021/jp025844e

[23] Heimer, T.A., Heilweil E.J., et al. (2000) Electron Injection, Recombination, and Halide Oxidation Dynamics at Dye-Sensitized Metal Oxide Interfaces. The Journal of Physical Chemistry A, 104, 4256-4262. https://doi.org/10.1021/jp993438y

[24] Kuciauskas, D., Monat, J.E., Villahermosa, R., Gray, H.B., Lewis, N.S. and McCusker, J.K. (2002) Transient Absorption Spectroscopy of Ruthenium and Osmium Polypyridyl Complexes Adsorbed onto Nanocrystalline $\mathrm{TiO}_{2}$ Photoelectrodes. The Journal of Physical Chemistry B, 106, 9347-9358. https://doi.org/10.1021/jp014589f

[25] Zhao, C. and Wittstock, G. (2004) Scanning Electrochemical Microscopy of Quino- 
protein Glucose Dehyd Rogenase. Analytical Chemistry, 76, 3145-3154. https://doi.org/10.1021/ac035492n

[26] Tefashe, U.M., Nonomura, K., Vlachopoulos, N., Hagfeldt, A. and Wittstock, G. (2012) Effect of Cation on Dye Regeneration Kinetics of N719-Sensitized $\mathrm{TiO}_{2}$ Films in Acetonitrile-Based and Ionic-Liquid-Based Electrolytes Investigated by Scanning Electrochemical Microscopy. The Journal of Physical Chemistry C, 116, 4316-4323. https://doi.org/10.1021/jp207671w

[27] Tefashe, U.M., Rudolph, M., Miura, H. and Wittstock, D.S. (2010) Photovoltaic chara Cteristics and Dye Regeneration Kinetics in D149-Sensitized ZnO with Varied Dye Loading and Film Thickness. Physical Chemistry Chemical Physics, 7533-7542. https://pubmed.ncbi.nlm.nih.gov/ https://doi.org/10.1039/c2cp40798a

[28] Shen, Y., Nonomura, K., Schlettwein, D., Zhao, C. and Wittstock, G. (2006) Photoelectrochemical kinetics of Eosin $\mathrm{Y}$-sensitized zinc oxide films investigated by scanning electrochemical Microscopy. Chemistry: A European Journal, 12, 5832-5839. https://doi.org/10.1002/chem.200501241

[29] Shen, Y., Tinashe, U.M., Nonomurab, K., Loewenstein, T., Schlettwein, D. and Witt stock, G. (2009) Photoelectrochemical Kinetics of Eosin Y-Sensitized Zinc Oxide Films Investigated by Scanning Electrochemical Microscopy under Illumination with Different LED. Electrochimica Acta, 55, 458-464.

https://doi.org/10.1016/j.electacta.2009.08.062

[30] Zhang, X.L., Huang, F.Z., Nattestad, A., et al. (2011) Enhanced Open-Circuit Voltage of p-Type DSC with Highly Crystalline NiO Nanoparticles. Chemical Communications, 47, 4808-4810. https://doi.org/10.1039/c0cc05445c

[31] Alemu, A.G. and Alemu, T. (2021) Dye Regeneration Kinetics of Sensitized Nickel Oxide Films under Illumination Investigated by Scanning Electrochemical Microscopy. Advances in Materials Physics and Chemistry, 11, 78-92. https://doi.org/10.4236/ampc.2021.114008

[32] Zhang, X., Leddy, J. and Bard, A.J. (1985) Dependence of Rate Constants of Heterogeneous Electron Transfer Reactions on Viscosity. Journal of the American Chemical Society, 107, 3719-3721. https://doi.org/10.1021/ja00298a054

[33] Cornut, R. and Lefrou, C. (2008) New Analytical Approximation of Feedback Approach Curves with a Micro Disk SECM Tip and Irreversible Kinetic Reaction at the Substrate. Journal of Electroanalytical Chemistry, 621, 178-184. https://doi.org/10.1016/j.jelechem.2007.09.021

[34] Mirabel, A. and Barton, S.C. (2021) Numerical Correction of in Situ AFM-SECM Measurements. Analytical Chemistry, 93, 12495-12503.

https://doi.org/10.1021/acs.analchem.1c00770

[35] Wittstock, G., Burchardt, M., Pust, S.E., Shen, Y. and Zhao, C. (2007) Scanning Electrochemical Microcopy for Direct Imaging of Reaction Rates. Angewandte Chemie International Edition, 46, 1584-1617. https://doi.org/10.1002/anie.200602750

[36] Liljeroth, P., Vanmaekelbergh, D., Ruiz, V., Kontturi, K., Jiang, H., Kauppinen, E. and Quinn, B.M. (2004) Electron Transport in Two-Dimensional Arrays of Gold Nanocrystals Investigated by Scanning Electrochemical Microscopy. Journal of the American Chemical Society, 126, 7126-7132. https://doi.org/10.1021/ja0493188

[37] Liu, B., Bard, A.J., Mirkin, M.V. and Creager, S.E. (2004) Electron Transfer at SelfAssembled Mono Layers Measured by Scanning Electrochemical Microscopy. Journal of the American Chemical Society, 126, 1485-1492.

https://doi.org/10.1021/ja038611p 
[38] Bozic, B. and Figgemeier, E. (2006) Scanning Electrochemical Microscopy under Illumination: An Elegant Tool to Directly Determine the Mobility of Charge Carriers within Dye-Sensitized Nanostructured Semiconductors. Chemical Communications, 2268-2270. https://doi.org/10.1039/b601587e

[39] Figgemeier, E., Kylberg, W.H. and Bozic, B. (2006) Scanning Photo-Electrochemical Microscopy as a Versatile Tool to Investigate Dye-Sensitized Nano-Crystalline Surfaces for Solar cells. SPIE: The International Society for Optical, 6197, 619711. https://doi.org/10.1117/12.662726

[40] Haram, S.K. and Bard, A.J. (2001) Scanning Electrochemical Microscopy. 42. Studies of the Kinetic and Photoelectrochemistry of Thin Film CdS/Electrolyte Interfaces. The Journal of Physical Chemistry B, 105, 8192-8195. https://doi.org/10.1021/jp011068j

[41] Tefashe, U.M., Loewenstein, T., Miura, H., Schlettwein, D. and Wittstock, G. (2010) Scanning Electrochemical Microscope Studies of Dye Regeneration in Indoline (D149)-Sensitized ZnO Photoelectrochemical Cells. Journal of Electroanalytical Chemistry, 650, 24-30. https://doi.org/10.1016/j.jelechem.2010.09.014

[42] Morandeira, A., Boschloo, G., Hagfeldt, A. and Hammarstro, L. (2008) Coumarin 343-NiO Films as Nanostructured Photocathodes in Dye-Sensitized Solar Cells: Ultrafast Electron Transfer, Effect of the $\mathrm{I}^{3-} / \mathrm{I}^{-}$Redox Couple and Mechanism of Photocurrent Generation. The Journal of Physical Chemistry C, 112, 9530-9537. https://doi.org/10.1021/jp800760q

[43] Morandeira, A., Boschloo, G., Hagfeldt, A. and Hammarström, L. (2005) Photoinduced Ultrafast Dynamics of Coumarin 343 Sensitized p-Type-Nanostructured NiO Films. The Journal of Physical Chemistry B, 109, 19403-19410.

https://doi.org/10.1021/jp053230e

[44] Borgstrom, M., Blart, E., Boschloo, G., Mukhtar, E., Hagfeldt, A., Hammarström, L. and Odobel, F. (2005) Sensitized Hole Injection of Phosphorus Porphyrin into NiO: Toward New Photovoltaic Devices. The Journal of Physical Chemistry B, 109, 2292822934. https://doi.org/10.1021/jp054034a

[45] Peng, Q., Joanna, W., Elizabeth, A., Gibson, E.A., Linder, M., Li, L., Brinck, L., Hagfeldt, A., Albinsson, B. and Sun, L.C. (2010) Synthesis and Mechanistic Studies of Organic Chromophores with Different Energy Levels for p-Type Dye-Sensitized Solar Cells. The Journal of Physical Chemistry C, 114, 4738-4748. https://doi.org/10.1021/jp911091n

[46] Alemu, G., Zhang, B., Li, J., Xu, X., Cui, J., Shen, Y. and M. Wang (2014) Investigation of Dye Regeneration Kinetics at dye-Sensitized p-Type Cucro2 Film/Electrolytes Interface with Scanning Electrochemical Microscopy. NANO: Reports and Reviews, 9, 1440008. https://doi.org/10.1142/S1793292014400086

[47] Alemu, G., Cui, J., Cao, K., Li, J., Shen, Y. and Wang, M. (2014) Investigation of the Regeneration Kinetics of Organic Dyes with Pyridine Ring Anchoring Groups by Scanning Electrochemical Microscopy. RSC Advances, 4, 51374-51380. https://doi.org/10.1039/C4RA07908F

[48] Alemu, G., Li, J.P., Cui, J., Xu, X.B., et al. (2015) Investigation on Regeneration Kinetics at Perovskite/Oxide Interface with Scanning Electrochemical Microscopy. Journal of Materials Chemistry A, 3, 9216-9222. https://www.researchgate.net/ https://doi.org/10.1039/C4TA06126H

[49] Morandeira, A., Fortage, J., Edvinsson, T., Le Pleux, L., Blart, E., Boschloo, G., Hagfeldt, A., Hammarström, L. and Odobel, F. (2008) Improved Photon-to-Current Conversion Efficiency with a Nanoporous p-Type NiO Electrode by the Use of a Sensitizer-Acceptor dyad. The Journal of Physical Chemistry C, 112, 1721-1728. https://doi.org/10.1021/jp077446n 


\section{Supporting Information}

\section{SI.1. Fitting of Steady-State SECM Approach Curves}

Normalized heterogeneous rate constants $\kappa$ and $k_{\text {eff }}$ have been extracted from experimental approach curves by fitting them to an analytical approximation of simulated data evaluated by Cornut and Lefrou [1] [3]. The analytical approximation of Cornut and Lefroul was used for calculating a theoretical current $I_{T}$ for each experimental, normalized distance. The formula of Amphlett and Denuault given for $R G=10$. Constants for other selected $R G$ are also available [2] [4]. Normalized approach curves $I_{T}$ vs. $L$ have been calculated from each experimental approach curves $i_{T}(z)$ using $I_{T}=i_{T} / i_{T, \infty}$ and $L=d / r_{T}$.

The fitting of the normalized approach curves yields a dimensionless normalized rate constant $k$. With the knowledge of $r_{T}$ and the diffusion coefficient of $\mathrm{I}_{3}$ in the electrolyte, an effective heterogeneous first order rate constant $k_{\text {eff }}\left[\mathrm{cm} \cdot \mathrm{s}^{-1}\right]$ is obtained.

$$
k_{\text {eff }}=\kappa \frac{D}{r_{T}}
$$

\section{SI.2. SECM Approach Curves on C343/NiO Sample}

In NiO DSSCs, visible light absorption by dyes is followed by hole injection from the excited dye to valence band of the semiconductor. The dye is then regenerated by electron transfer from the reduced dye to the oxidized species $\left(\mathrm{I}_{3}^{-}\right)$in the electrolyte. If the reduced dye cannot react with the electrolyte within the charge-separated lifetime, it may recombine with the hole in the semiconductor geminate recombination. The holes in the semiconductor move to the back collector of the working electrode and the reduced species $\left(\mathrm{I}^{-}\right)$in the electrolyte diffuses to the Pt electrode. This charge collection gives rise to a cathodic photocurrent in the external circuit. On the basis of the former studies, the following mechanism can be proposed: Upon excitation of the dye, charge separation occurs.
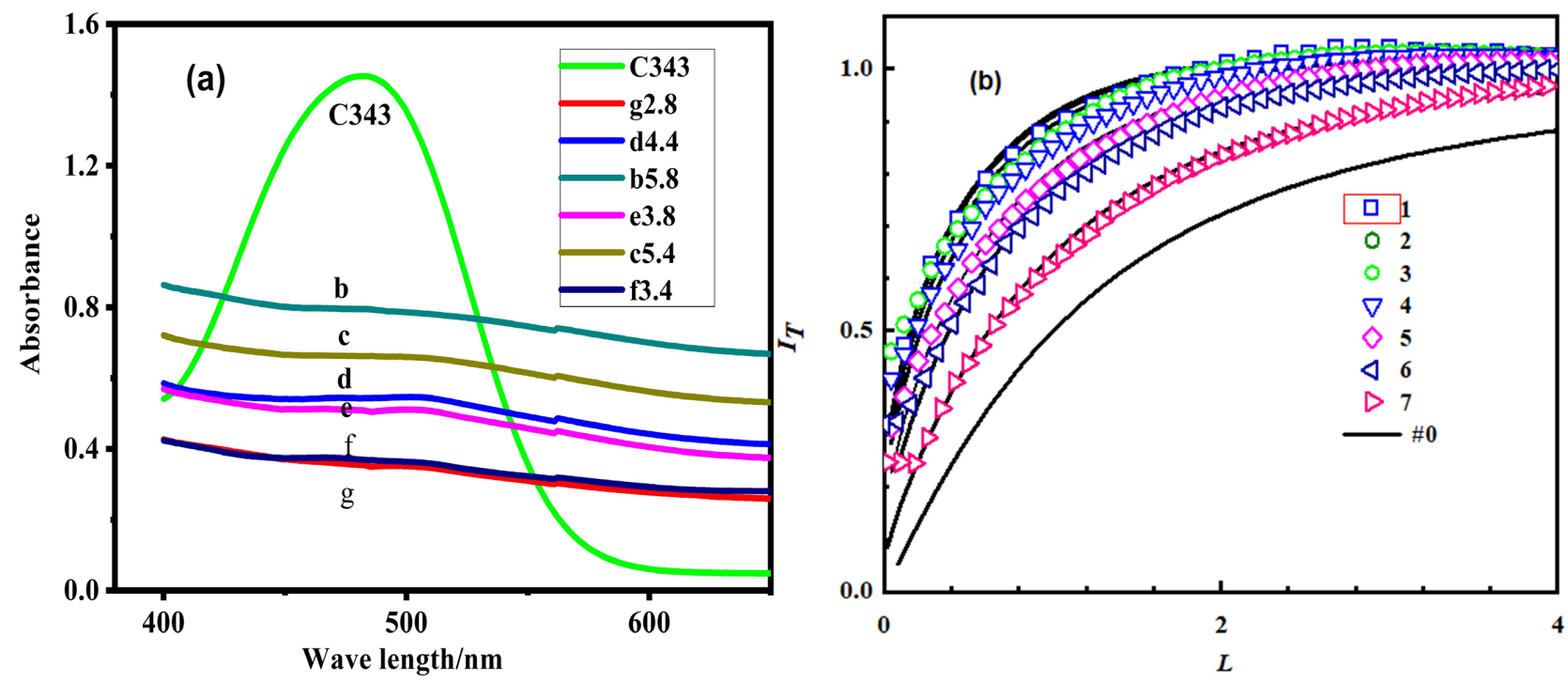

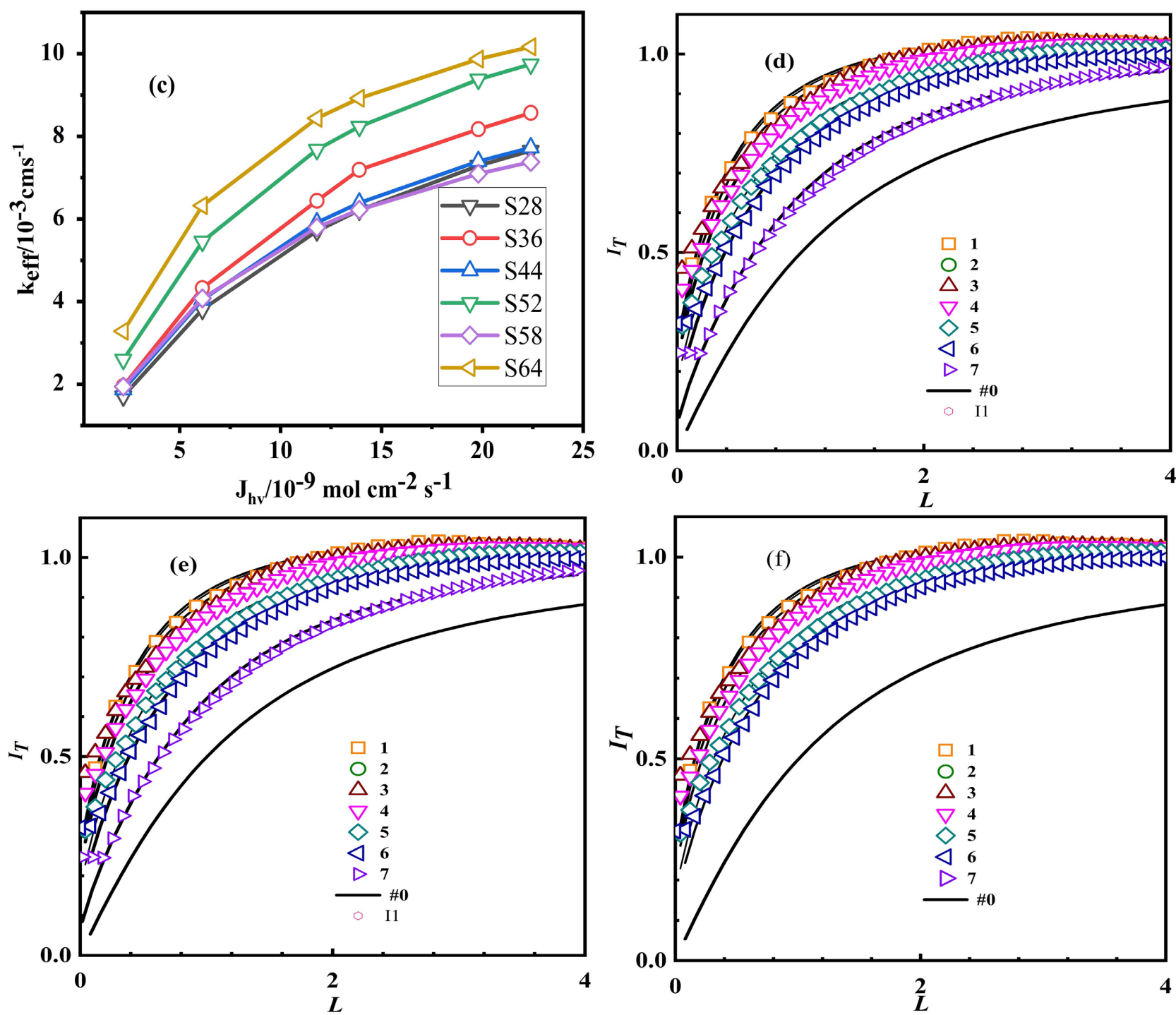

Figure S1. Normalized SECM feedback approach curves for the approach of a Pt disk UME towards a NiO/C343 film in the dark (curve 1) and under illumination by a blue LED electrolyte $1 \mathrm{mM} \mathrm{I}+0.1 \mathrm{MLiTFS}$. Photon flux density of LED in $10^{-9} \mathrm{~mol} \cdot \mathrm{cm}^{-2} \cdot \mathrm{s}^{-1}$ (2) 2.2 , (3) 6.1, (4) $11.8,(5) 13.9,(6) 19.8$ (7) 22.4; $v_{T}=0.05 \mathrm{mV} \cdot \mathrm{s}^{-1}, E_{T}=0.7 \mathrm{~V},\left[\mathrm{I}^{-}\right] \mathrm{k}:$ (a) Optical absorption spectra of NiO/C343 films of different thickness. (b) Sample thickness $3.6 \mu \mathrm{m}$ (1) 0.0161 , (2) 0.0384 , (3) 0.0399 , (4) 0.0427 (5) 0.0472 (6) 0.0481 and corresponding $k_{\text {eff }} \times 10^{-3} \mathrm{~cm} \cdot \mathrm{s}^{-1}$ (1) 0.23 , (2) 0.48 , (3) 0.52 , (4) 0.63 , (5) 0.7 , (6) 0.75 . $k_{\text {eff }}$ vs. $J_{\text {hv }}$ for six different C343-sensitized NiO photoelectrodes with systematically varied thickness. (d) thickness $4.4 \mu \mathrm{m} \mathrm{k}$ (1) 0.0197, (2) 0.0394, (3) 0.0438 , (4) 0.0509 , (5) 0.0523 , (6) 0.0583 and corresponding $k_{\text {eff }} \times 10^{-3} \mathrm{~cm} \cdot \mathrm{s}^{-1}$ (1) 0.29 , (2) 0.56 , (3) 0.59 (4) 0.69 (5) 0.74 (6) 0.86 . (e) Thickness $5.4 \mu \mathrm{m} \mathrm{k}$ (1) 0.0243 , (2) 0.0324, (3) 0.0351 , (4) 0.0433 , (5) 0.0501 , (6) 0.0609 and corresponding $k_{\text {eff }} \times 10^{-3} \mathrm{~cm} \cdot \mathrm{s}^{-1}$ (1) 0.36 , (2) 0.59 , (3) 0.65 , (4) 0.76 , (5) 0.83, (6) 1.1. (f) Thickness $5.8 \mu \mathrm{m} \mathrm{k}$ (1) 0.0396, (2) 0.0481, (3) 0.0512, (4) 0.0611, (5) 0.0682, (6) 0.0774 and corresponding $k_{\text {eff }} \times 10^{-3} \mathrm{~cm} \cdot \mathrm{s}^{-1}$ (1) 0.59 , (2) 0.72 , (3) 0.76 , (4) 0.91, (5) $1.01,(6) 1.5$.

Table S1. Normalized rate constants rate constants $k_{\text {eff }}=k D / r_{T}$ obtained for the reduction of photo excited

\begin{tabular}{ccccccc}
\hline \multicolumn{5}{c}{$J_{\text {hv }}$} & \multicolumn{5}{c}{$k_{\text {eff }} / 10^{-3} \mathrm{~cm} \cdot \mathrm{s}^{-1}$} \\
\hline $\mathrm{Jhv} / 10^{-9}$ & $2.8 \mu \mathrm{m}$ & $34 \mu \mathrm{m}$ & $38 \mu \mathrm{m}$ & $44 \mu \mathrm{m}$ & $54 \mu \mathrm{m}$ & $58 \mu \mathrm{m}$ \\
\hline 22.4 & 7.65 & 8.57 & 7.73 & 7.38 & 9.75 & 10.17 \\
19.8 & 7.29 & 8.18 & 7.39 & 7.11 & 9.38 & 9.87 \\
\hline
\end{tabular}




\begin{tabular}{ccccccc} 
Continued & \multicolumn{7}{c}{} \\
\hline 13.9 & 6.21 & 7.19 & 6.39 & 6.22 & 8.24 & 8.92 \\
11.8 & 5.71 & 6.44 & 5.91 & 5.81 & 7.68 & 8.44 \\
6.12 & 3.81 & 4.33 & 4.05 & 4.08 & 5.45 & 6.33 \\
2.21 & 1.71 & 1.96 & 1.87 & 1.94 & 2.61 & 3.28 \\
$k_{\text {red }}$ & $4.89 \times 10^{5}$ & $5.15 \times 10^{5}$ & $4.4 \times 10^{5}$ & $4.1 \times 10^{5}$ & $4.46 \times 10^{5}$ & $5.14 \times 10^{5}$ \\
$\Gamma_{\mathrm{D}}$ & $8.21 \times 10^{-8}$ & $8.4 \times 10^{-8}$ & $10.2 \times 10^{-8}$ & $10.8 \times 10^{-8}$ & $11.4 \times 10^{-8}$ & $13.2 \times 10^{-8}$ \\
$A$ & $4.31 \times 10^{-7}$ & $4.872 \times 10^{-7}$ & $5.916 \times 10^{-7} 6.264 \times 10^{-7}$ & $6.612 \times 10^{-7}$ & $7.566 \times 10^{-7}$ \\
\hline
\end{tabular}

A hole is injected into the $\mathrm{NiO}$ valence band, and the dye is reduced. The reduced dye will react with the oxidized species $\left(\mathrm{I}_{3}^{-}\right)$of the electrolyte and regenerate to its ground state. In this case, $\mathrm{I}_{2}^{--}$would be generated, which is also a common intermediate in NiO based solar cells [5] [6] (Table S1 \& Figure S1).

\section{References}

[1] R. Cornut and C. Lefrou, J. Electroanal. Chem., 2008, 621, 178-184.

[2] J. L. Amphlett and G. Denuault, J. Phys. Chem. B, 1998, 102, 9946-9951.

[3] U. M. Tefashe, Nonomura, K.; N. Vlachopoulos; A. Hagfeldt, G. Wittstock, J. Phys. Chem. C, 2012, 116, 4316-4323.

[4] Y. Shen, U. M. Tefashea, K. Nonomurab, T. Loewenstein, D. Schlettwein, G. Wittstock, Electroc Himica Acta, 2009, 55, 458-464.

[5] Y. Shen, K. Nonomura, D. Schlettwein, C. Zhao, G. Wittstock J. of Electroanalytical Chemistry, 2010, 650, 24-30.

[6] G. Wittstock, M. Burchardt, S. E. Pust, Y. Shen, C. Zh, Angew. Chem. Int. Ed., 2007, 46, 1584-1617. 